\title{
THE EFFECT OF MANNITOL AND SORBITOL ON SOYBEAN IN VITRO DEVELOPMENT
}

\section{WPŁYW MANNITOLU I SORBITOLU NA ROZWÓJ SOI W KULTURACH IN VITRO}

\author{
Department of Plant Genetic, Breeding and Biotechnology, West Pomeranian University \\ of Technology, Szczecin, Poland \\ 1Department of Physics and Agrophysics, West Pomeranian University of Technology, Szczecin, \\ Poland
}

\begin{abstract}
Streszczenie. Celem pracy było określenie wpływu symulowanej suszy, indukowanej mannitolem (Mn) lub sorbitolem (So) w stężeniu 0-200 mM, na kiełkowanie nasion i wzrost siewek soi zwyczajnej (Glycine max L.) w kulturach in vitro. Analizy efektywności porcesu dokonano poprzez ocenę długości łodyg i korzeni oraz świeżej i suchej masy 3-tygodniowych siewek. Wartości wskaźników biometrycznych różniły się w zależności od rodzaju zastosowanej substancji. Mn w najniższym stężeniu (50 mM) nie wpływał na badane parametry biometryczne, natomiast So (50 mM) stymulował wzrost siewek, wydłużanie się korzeni oraz wzrost liczby liści i świeżej masy roślin. Niekorzystny efekt na biomasę zanotowano dopiero przy wyższych stężeniach obydwu substancji. Mn (>50 mM - <150 mM) negatywnie wpływał na kształtowanie się świeżej i suchej masy siewek. Z kolei Mn (150 i $200 \mathrm{mM}$ ) powodował ponadto zahamowanie wzrostu, zmniejszenie liczby i długości liści.So (200 mM) znacznie hamował wzrost siewek, zmniejszając suchą masę.
\end{abstract}

Key words: drought, Gycine, mannitol, in vitro selection, osmotic stress, sorbitol.

Słowa kluczowe: susza, Gycine, mannitol, selekcja in vitro, stres osmotyczny, sorbitol.

\section{INTRODUCTION}

Drought is an environmental stress causing a huge loss in agricultural production; therefore, efforts aimed at the breeding of new varieties, tolerant to abiotic stresses, are of great significance for crop yield increase (Rai et al. 2011; Magyar-Tábori et al. 2011). The first stage of each breeding process, which concurrently determines its success, is a precise define of the range of given feature variability in population and the selection of individuals, in this case characterised by an increased tolerance to a given stress factor. The method used to determine plants tolerance to abiotic stress factors is the selection in in vitro conditions, which allow for easy handling of the medium composition. Thus, the plants characterised by

Corresponding author - Adres do korespondencji: Danuta Kulpa, Department of Plant Genetics, Breeding and Biotechnology, West Pomeranian University of Technology, Szczecin, Juliusza Słowackiego 17, 71-434 Szczecin, Poland, e-mail: danuta.kulpa@zut.edu.pl 
an increased tolerance to a given factor may be selected in a simple, and concurrently repeatable and precise manner (Rzepka-Plevneš and Kulpa 1999; Rzepka-Plevneš et al. 2006). This is a relatively cheap method allowing a large number of plants to be examined in repeatable, controlled conditions.

The factor inducing osmotic stress in in vitro cultures on agar media is usually the addition of mannitol (Mohamed et al. 2000; Errabii et al. 2006; Matheka et al. 2008; Mienie and Ronde 2008; Cha-Um et al. 2014; Snyman et al. 2016) or sorbitol (Al-Khayri and Al-Bahrany 2002; Molassiotis et al. 2006; Bündig et al. 2017), an increased content of saccharose in medium (Ikeda-Iwai et al. 2003), or an enhanced strength of medium gelation, reducing water availability to plants obtained by an increase in the agar concentration in the culture medium (Rzepka-Plevneš et al. 2008).

However, to apply this method with respect to particular plant species, it is essential to precisely select the kind and concentration of selection factors in medium for the examined plant genotypes, as it can significantly affect plant development, but should not concurrently cause decay. Currently, there are no literature reports concerning soybean seedlings tolerance to the osmotic stress under in vitro conditions. The only reports concern the impact of osmotic stress on development, especially the maturation and hardening of embryos obtained by somatic embryogenesis (Walker and Parrott 2001; Schmidt et al. 2005; Yang et al. 2009). Therefore, the aim of this study was to determine an effect of mannitol and sorbitol on in vitro seed germination and development of common soybean (Glycine max L.) seedlings.

\section{MATERIAL AND METHODS}

\section{Seed germination and plant growth conditions}

Plant material for the experiment included the seeds of common soybean (Glycine max L.) of $\mathrm{cv}$. Aldana. The seeds for initiation of the culture were obtained from voucher specimen from the Plant Breeding and Acclimatization Institute - National Research Institute, Poland. Seeds were sterilised with $70 \%$ solution of ethyl alcohol for $10 \mathrm{~s}$, and then in $0.2 \% \mathrm{HgCl}_{2}$ for $10 \mathrm{~min}$. Disinfected seeds (10 per one jar) were placed on an MS medium (Murashige and Skoog 1962) with the addition of $50,100,150$ or $200 \mathrm{mM}$ sorbitol or mannitol. As a control MS ( $\mathrm{pH}$ 5.7) medium without mannitol or sorbitol was used. The medium was solidified with $8 \mathrm{~g} \cdot \mathrm{dm}^{-3}$ of agar and sterilised $\left(20 \mathrm{~min}\right.$ at $121^{\circ} \mathrm{C}$ and $\left.1.03 \mathrm{kPa}\right)$. The Petri dishes with seeds were placed in a phytotron at $24^{\circ} \mathrm{C}$ for 21 days and relative air humidity of $70-80 \%$. The in vitro cultures were kept under a fluorescence light with intensity of $40 \mu \mathrm{mol} \cdot \mathrm{m}^{-2} \cdot \mathrm{s}^{-1}$ photosynthetic active radiation (PAR) supplied by Philips TLD $36 \mathrm{~W} / 33$ cool-white fluorescent lamps, for $16 \mathrm{~h}$ per day. Experiments were conducted under a randomised block design including 10 replicates with 100 seedlings per treatment.

\section{Plant phenotypying}

Cultures were conducted three weeks, and after that morphological features including plant height [cm], root length [cm], fresh and dry mass of plants [g] were determined. Dry mass of the plants or their fragments was measured after previous drying at a temperature of $105^{\circ} \mathrm{C}$ to solid mass. Microbiometric measurements (determination of the length and number 
of stomata on leaves, as well as epidermal cells length) were made using a scanning electron microscope (FEI Quanta200), with an accelerating voltage of $200 \mathrm{kV}$. Fresh fragments of leaves from the second node were collected for the examinations, and were placed in a vacuum chamber of the microscope. The measurements were made on fresh plant material without previous fixing and spraying. To study the number and length of stomata, 25 photographs were taken of randomly selected areas of each leaf sample at 1000 x magnification. Statistical analysis for microbiometric measurements was performed using Statistica 10.0 software; uniform groups were determined using Tukey's test at the confidence level of $P \leq 0.05$.

\section{RESULTS AND DISCUSSION}

Common soybean (Glycine max L.) is a plant which is more commonly cultivated in Europe, due to the wide range of applications. The problem in the case of European cultivations is the insufficient resistance of this species to abiotic stresses, including salinity and water deficiencies. The in vitro method, imitating drought stress, allowsthe easy and quick determination of plant tolerance to osmotic stress and could be used for theselection of in vitro culture conditions. However, in order for the selection to be successful, the kind and concentration of substances inducing osmotic stress that are added to the medium should be determined in a precise manner. In this study, proposed medium modifications with mannitol or sorbitol in subsequent concentrations $(0-200 \mathrm{mM})$ allow to obtain all the seeds germinated.

Mannitol is usually added to the media at concentrations from 50 to $700 \mathrm{mM}$, depending on the genotype of the examined plants. Balen et al. (2013) tested the tolerance of Mamillaria cactus by placing fragments of the plants on the media containing $150 \mathrm{mM}$ of mannitol, while Watanabe et al. (2000) selected the clones of Populus crossbreds using a higher concentration, i.e. $200 \mathrm{mM}$. Gangopadhyay et al. (1997) conducted the selection of Brassica juncea tolerant to stress conditions by placing the fragments of callus tissue on MS media with the addition of $165 \mathrm{mM}$ of mannitol; however, the tolerant lines extracted were tested on media containing as much as $329 \mathrm{mM}$ of mannitol. An even higher concentration of mannitol in the medium was used by Kehie et al. (2012), who examined the effect of osmotic stress on capsaicin production by Capsicum chinense. They added mannitol at concentration from 82.34 to $658.72 \mathrm{mM}$ to the medium; even in the case of the highest concentration used, they observed plant growth and development. In this study, it is presented, that plants height and leaves number decreased under proposed conditions. While, mannitol $50 \mathrm{mM}$ did not affect the development of soybean seedlings, $100 \mathrm{mM}$ mannitol only limited two biomass parameters: the fresh and dry weight of the plants. In the case of plants growing on media supplemented with 150 and $200 \mathrm{mM}$ mannitol, the height of the plants was $71 \%$ and $49 \%$ of the control, respectively, and the plants formed sparse leaves (Table 1). As demonstrated by numerous researchers, saline or osmotic stress in particular strongly affect the formation of the underground part of plants. It was noted in this study that the addition of mannitol to the media inhibited the development of the root system when used at concentrations above $100 \mathrm{mM}$. 
Table 1. Mean values $(x)$ for morphological traits of soybean seedlings on MS medium with different concentrations of mannitol Tabela 1. Wartości cech morfologicznych siewek soi na pożywce MS z dodatkiem różnych stężeń mannitolu

\begin{tabular}{|c|c|c|c|c|c|c|c|c|}
\hline \multirow{3}{*}{$\begin{array}{l}\text { Morphological trait } \\
\text { Cecha morfologiczna }\end{array}$} & \multicolumn{8}{|c|}{ Concentration of mannitol - Stężenie mannitolu [mM] } \\
\hline & \multicolumn{2}{|c|}{50} & \multicolumn{2}{|c|}{100} & \multicolumn{2}{|c|}{150} & \multicolumn{2}{|c|}{200} \\
\hline & $x$ & $\begin{array}{l}\text { percentage } \\
\text { of control } \\
\text { procent kontroli }\end{array}$ & $x$ & $\begin{array}{l}\text { percentage of } \\
\text { control } \\
\text { procent kontroli }\end{array}$ & $x$ & $\begin{array}{l}\text { percentage of } \\
\text { control } \\
\text { procent kontroli }\end{array}$ & $\mathrm{x}$ & $\begin{array}{l}\text { percentage of } \\
\text { control } \\
\text { procent kontroli }\end{array}$ \\
\hline $\begin{array}{l}\text { Plant height } \\
\text { Wysokość roślin [cm] }\end{array}$ & $18.25 \pm 3.89$ & 89 & $17.18 \pm 3.68$ & 84 & $14.54 \pm 3.82$ & 71 & $10.04 \pm 4.18$ & 49 \\
\hline $\begin{array}{l}\text { Roots length } \\
\text { Długość korzeni [cm] }\end{array}$ & $18.51 \pm 3.02$ & 113 & $15.80 \pm 6.17$ & 96 & $9.29 \pm 4.17$ & 57 & $5.39 \pm 2.08$ & 33 \\
\hline $\begin{array}{l}\text { Leaves number } \\
\text { Liczba liści }\end{array}$ & $7.77 \pm 2.62$ & 93 & $6.20 \pm 4.03$ & 75 & $5.10 \pm 3.07$ & 61 & $1.50 \pm 0.81$ & 18 \\
\hline $\begin{array}{l}\text { Fresh mass } \\
\text { Świeża masa [g] }\end{array}$ & $2.20 \pm 0.74$ & 95 & $1.84 \pm 0.29$ & 80 & $1.46 \pm 0.45$ & 63 & $0.86 \pm 0.13$ & 37 \\
\hline $\begin{array}{l}\text { Dry mass } \\
\text { Sucha masa [g] }\end{array}$ & $0.32 \pm 0.42$ & 107 & $0.22 \pm 0.24$ & 73 & $0.19 \pm 0.30$ & 63 & $0.15 \pm 0.13$ & 50 \\
\hline
\end{tabular}

Control - seedlings from MS medium - Kontrola - siewki z pożywki MS.

Table 2. Mean values $(\mathrm{x})$ for morphological traits of soybean seedlings on MS media with different concentrations of sorbitol

Tabela 2. Wartości cech morfologicznych siewek soi na pożywce MS z dodatkiem różnych stężeń sorbitolu

\begin{tabular}{|c|c|c|c|c|c|c|c|c|}
\hline \multirow{3}{*}{$\begin{array}{l}\text { Morphological trait } \\
\text { Cecha morfologiczna }\end{array}$} & \multicolumn{8}{|c|}{ Concentration of sobitol - Stężenie sorbitolu [mM] } \\
\hline & \multicolumn{2}{|c|}{50} & \multicolumn{2}{|c|}{100} & \multicolumn{2}{|c|}{150} & \multicolumn{2}{|c|}{200} \\
\hline & $\mathrm{x}$ & $\begin{array}{c}\text { percentage } \\
\text { of control } \\
\text { procent kontroli }\end{array}$ & $x$ & $\begin{array}{l}\text { percentage } \\
\text { of control } \\
\text { procent kontroli }\end{array}$ & $\mathrm{x}$ & $\begin{array}{c}\text { percentage } \\
\text { of control } \\
\text { procent kontroli }\end{array}$ & $x$ & $\begin{array}{c}\text { percentage } \\
\text { of control } \\
\text { procent kontroli }\end{array}$ \\
\hline $\begin{array}{l}\text { Plant height } \\
\text { Wysokosć roślin [cm] }\end{array}$ & $20.27 \pm 4.22$ & 99 & $20.60 \pm 4.88$ & 100 & $18.21 \pm 4.11$ & 89 & $15.12 \pm 3.68$ & 74 \\
\hline $\begin{array}{l}\text { Roots length } \\
\text { Długość korzeni [cm] }\end{array}$ & $17.73 \pm 4.21$ & 108 & $16.23 \pm 5.75$ & 99 & $16.19 \pm 6.82$ & 99 & $15.13 \pm 4.57$ & 92 \\
\hline $\begin{array}{l}\text { Leaves number } \\
\text { Liczba liści }\end{array}$ & $10.73 \pm 3.92$ & 129 & $9.60 \pm 3.56$ & 115 & $7.90 \pm 2.29$ & 95 & $7.65 \pm 3.07$ & 92 \\
\hline $\begin{array}{l}\text { Fresh mass } \\
\text { Świeża masa [g] }\end{array}$ & $2.56 \pm 0.33$ & 111 & $2.19 \pm 0.31$ & 95 & $2.35 \pm 0.51$ & 102 & $1.96 \pm 0.31$ & 85 \\
\hline $\begin{array}{l}\text { Dry mass } \\
\text { Sucha masa [g] }\end{array}$ & $0.34 \pm 0.38$ & 113 & $0.31 \pm 0.44$ & 103 & $0.30 \pm 0.40$ & 100 & $0.26 \pm 0.42$ & 87 \\
\hline
\end{tabular}

Control - seedlings from MS medium - Kontrola - siewki z pożywki MS. 
In the case of the highest mannitol concentration used, i.e. $200 \mathrm{mM}$, root lengths only reached $33 \%$ of the length of control plant roots. Also, in the study by Aydi et al. (2008), the addition of $150 \mathrm{mM}$ mannitol to the medium inhibited the growth of roots, surface and length of the leaves, as well as dry matter of the bean of seedlings (Phaseolus vulgaris).

Sorbitol less inhibited seedling development, where compared to mannitol effect (Table 2). This compound even stimulated plant development when added to the media at the lowest concentration $(50 \mathrm{mM})$ - it affected elongation of the root system, and increased the number of leaves and growth in the fresh and dry mass of plants. These results are in agreement with Matuszak et al. (2009), who showed that the application of low doses of stress factors may stimulate plant growth. The authors demonstrated that the addition of small concentrations of $\mathrm{NaCl}(25 \mathrm{mM})$ caused an increase in fresh and dry mass of above-ground part and roots of wheat seedlings $\mathrm{cv}$. Almari. In this study, sorbitol inhibited seedling growth and affected the dry mass decrease only when it was added to the media at the highest concentration - $200 \mathrm{mM}$. This is consistent with the results of Rzepka-Plevnes et al. (2008), who led rye selection in terms of tolerance to drought, placing the germs on the medium containing $200 \mathrm{mM}$ sorbitol. Similar results were obtained by Wankhade et al. (2010), who examined rice tolerance to $\mathrm{NaCl}$ and osmotic stress by placing seeds on media containing as much as $300 \mathrm{mM}$ of sorbitol.

The effectiveness of water utilisation depends inter alia on the density of stomata arrangement on the leaves' surface and their opening regulation (Tanzarella et al. 1984; Nadeau and Sack 2002; Chinnusamy et al. 2004). The factors applied in the experiment which induced osmotic stress conditions also affected the formation of leaves, as well as the number and length of stomata on the leaf blades surface. The study was conducted in the case of experimental variants in which the formation of leaves with properly shaped leaf blades was observed, i.e. media containing sorbitol at a concentration of $50 \mathrm{mM}$, and mannitol at concentrations of 50,100 and $150 \mathrm{mM}$, as well as control plants (Table 3, Fig. 1).

Table 3. Number and length of stomata on the leaf blades surface of soybean seedlings growing on MS media with different concentrations of sorbitol and mannitol

Tabela 3. Liczba i długość aparatów szparkowych na powierzchni blaszek liściowych siewek soi rosnących na pożywce MS z dodatkiem różnych stężeń sorbitolu i mannitolu

\begin{tabular}{|c|c|c|c|c|c|}
\hline \multirow{3}{*}{$\begin{array}{l}\text { Morphological trait } \\
\text { Cecha morfologiczna }\end{array}$} & \multirow{3}{*}{$\begin{array}{l}\text { Control } \\
\text { Konrola }\end{array}$} & \multicolumn{4}{|c|}{$\begin{array}{l}\text { Concentration of } \\
\text { Stężenie [mM] }\end{array}$} \\
\hline & & \multicolumn{2}{|l|}{ sorbitol } & \multicolumn{2}{|c|}{ mannitol } \\
\hline & & 50 & 50 & 100 & 150 \\
\hline $\begin{array}{l}\text { Number of stomata on the leaf blades } \\
\text { surface [no./mm²] } \\
\text { Liczba aparatów szparkowych } \\
\text { na powierzchni blaszki liściowej } \\
\text { [liczba/mm²] }\end{array}$ & $65 \mathrm{~b}$ & $164,0 \mathrm{a}$ & $42 \mathrm{~b}$ & $38 \mathrm{~b}$ & $48 \mathrm{~b}$ \\
\hline 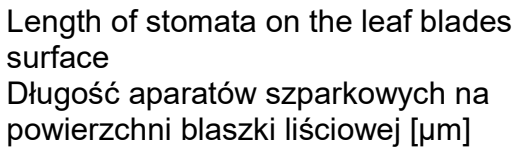 & $16.23 \mathrm{a}$ & $15.0 \mathrm{a}$ & $15.46 \mathrm{a}$ & $14.19 \mathrm{a}$ & $15.75 a$ \\
\hline
\end{tabular}

Control - seedlings from MS medium - Kontrola - siewki z pożywki MS. 


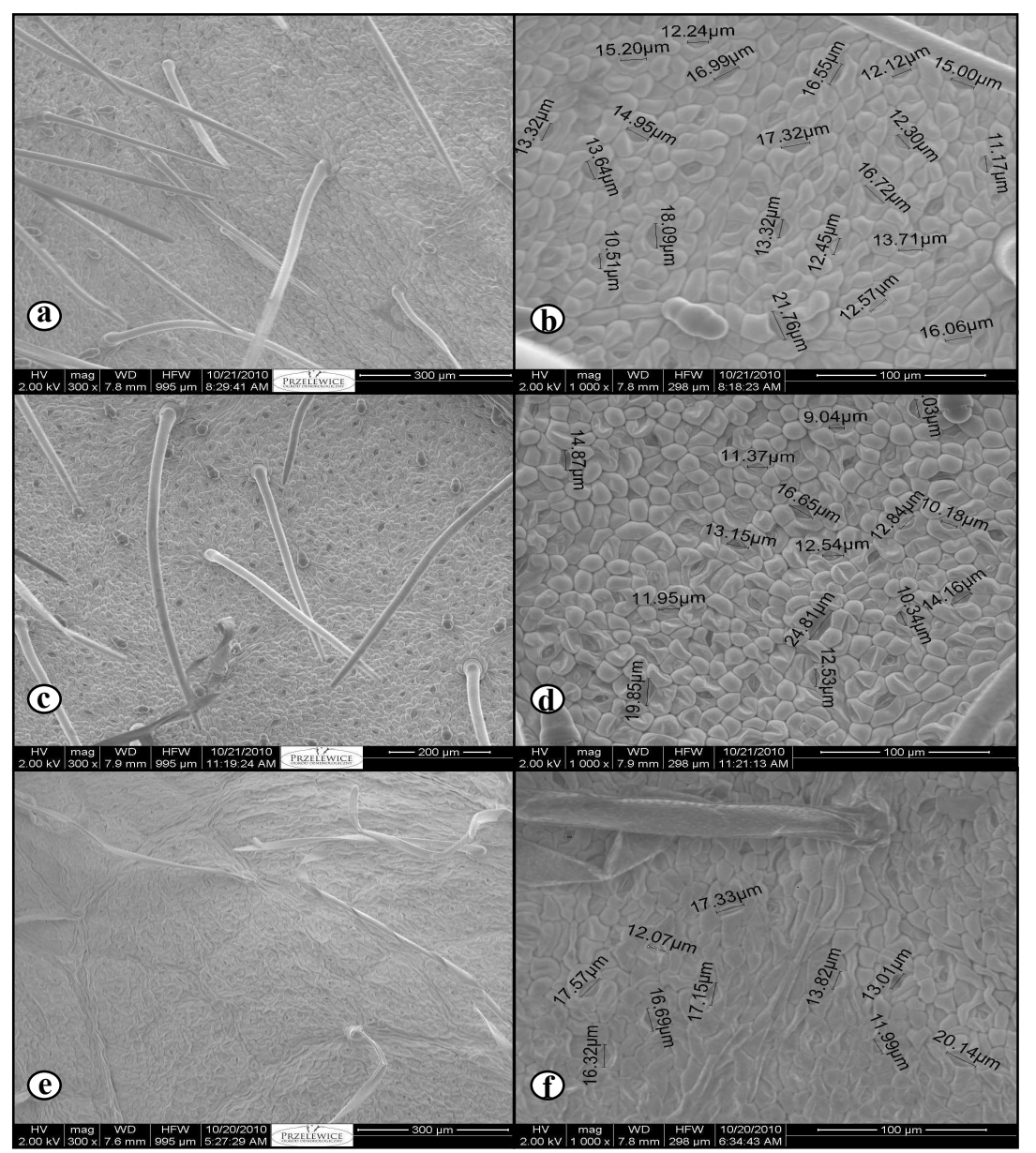

Fig. 1. The scanning electron microscope images showing the surface of the leaves (x 300 magnification) and stomata (magnification $x$ 1000), soybean plants growing on media: $a, b-c o n t r o l$, c, d, - containing $50 \mathrm{mM}$ sorbitol, e, $\mathrm{f}$ - containing $50 \mathrm{mM}$ mannitol

Ryc. 1. Obrazy mikroskopu elektronowego skaningowego przedstawiające powierzchnię liści (powiększenie x 300) i aparaty szparkowe (powiększenie x 1000), rośliny soi rosnące na podłożu: a, b - kontrola, c, d, - z 50 mM sorbitolu, e, f, - z 50 mM mannitolu

Only the addition of $50 \mathrm{mM}$ of sorbitol to the medium caused a statistically significant increase in the number of leaves' stomata compared to the control. The factors inducing a physiological drought (sorbitol and mannitol) caused a decrease in stomata' length. This is in agreement with the study of Mehri et al. (2009), who also noted a decrease in the number and length of stomata in the case of flag leaves of wheat in water deficiency conditions.

Presented work is a part of the research cycle aimed to determination of the tolerance of soybean varieties currently cultivated in Poland to the unprofitable environmental conditions. We proposed, based on biometric data obtained, that the in vitro method of seed germination on medium supplemented with mannitol or sorbitol at subsequent concentrations (0-200 mM) could be used for the qiuck selection of soybean genotyped resistant to the osmotic stress.

\section{CONCLUSION}

1. Osmotic stress factors used in the experiment, such as sorbitol and mannitol added to nutrient solution according to Murashige and Skoog (1962) had significant but different effects on the development of soybean seedlings (Glycine max) in in vitro cultures. 
2. Mannitol added to media at a concentration of 150 and $200 \mathrm{mM}$ inhibits soybean growth in in vitro cultures. Plants growing on media with the addition of this factor were lower, had a smaller number and length of leaves and a fresh and dry mass relative to the control plants.

3. Sorbitol added to the media at a concentration of $50 \mathrm{mM}$ stimulates the development of the root system and affects the increase in the number of leaves and fresh weight of plants. Sorbitol inhibits the growth of seedlings and reduces their dry matter only when added to the media at a concentration of $200 \mathrm{mM}$.

\section{REFERENCES}

Al-Khayri J.M., Al-Bahrany A.M. 2002. Callus growth and proline accumulation in response to sorbitol and sucrose-induced osmotic stress in rice. Biol. Plant. 45(4), 609-611.

Aydi S.S., Aydi S., Gonzalez E., Abdelly Ch. 2008. Osmotic stress affects water relations, growth, and nitrogen fixation in Phaseolus vulgaris plants. Acta Physiol. Plant. 30(4), 441-449.

Balen B., Tkalec M., Rogić T., Šimac M., Štefanić P.P., Rončević S., Svedružić L.P., Krsnik-Rasol M. 2013. Effects of iso-osmotic $\mathrm{NaCl}$ and mannitol on growth, proline content, and antioxidant defense in Mammillaria Gracilis Pfeiff. in vitro-grown cultures. In Vitro Cell. Dev. Biol. Plant. 49 (4), 421-432.

Bündig C., Vu T. H., Meise P., Seddig S., Schum A., Winkelmann T. 2017. Variability in osmotic stress tolerance of starch potato genotypes (Solanum tuberosum L.) as revealed by an in vitro screening: Role of proline, osmotic adjustment and drought response in pot trials. J. Agron. Crop Sci. 203(3), 206-218.

Cha-Um S., Somsueb S., Samphumphuang T., Kirdmanee C. 2014. Screening of eight eucalypt genotypes (Eucalyptus Sp.) for water deficit tolerance using multivariate cluster analysis. Appl. Biochem. Biot. 173(3), 753-764.

Chinnusamy V., Xiong L., Zhu J.K. 2004. Use of genetic engineering and molecular biology approaches for crop improvement for stress environments, in: Abiotic stress: plant resistance through breeding and molecular approaches. Eds. M. Ashraf, P.J.C. Harris. Birminghton, Food Products Press, 47-107.

Errabii T., Gandonou C.B., Essalmani H., Abrini J., Idomar M., Senhaji N.S. 2006. Growth, proline and ion accumulation in sugarcane callus cultures under drought-induced osmotic stress and its subsequent relief. Afr. J. Biot. 5, 1488-1493.

Gangopadhyay G., Basu S., Gupta S. 1997. In vitro selection and physiological characterization of $\mathrm{NaCl}$ - and mannitol-adapted callus lines in Brassica Juncea. Plant Cell Tissue Organ Cult. 50(3), 161-169.

Ikeda-Iwai M., Umehara M., Satoh S., Kamada H. 2003. Stress-induced somatic embryogenesis in vegetative tissues of Arabidopsis Thaliana. Plant J. 34(1), 107-114.

Kehie M., Kumaria S., Tandon P. 2012. Osmotic stress induced-capsaicin production in suspension cultures of Capsicum chinense Jacq. cv. Naga King Chili. Acta Physiol. Plant. 34, 2039-2044.

Magyar-Táborj K., Mendler-Drienyovszki N., Dobránszki J. 2011. models and tools for studying drought stress responses in peas. OMICS 15(12), 829-838.

Matheka J.M., Magiri E., Rasha A.O., Machuka J. 2008. In vitro selection and characterization of drought tolerant somaclones of tropical maize (Zea mays L.). Biotechnology 7(4), 641-650.

Matuszak R., Włodarczyk M., Brzóstowicz A., Wybieralski J. 2009. Wpływ NaCl na zawartość wybranych mikroelementów w liściach i korzeniach siewek pszenicy ozimej odmiany Almari. Acta Agroph. 14(1), 145-153. [in Polish] 
Mehri N., Fotovat R., Saba J., Jabbari F. 2009. Variation of stomata dimensions and densities in tolerant and susceptible wheat cultivars under drought stress. J. Food Agric. Envir. 7(1), 167-170.

Mienie A., De Ronde J.A. 2008. A comparison of drought stress and heat stress in the leaves and tubers of 12 potato cultivars. South Afr. J. Sci. 104(3-4), 156-159.

Mohamed M.A.H., Harris P.J.C., Henderson J. 2000. In vitro selection and characteri-zation of a drought tolerant clone of Tagetes minuta. Plant Sci. 159(2), 213-222.

Molassiotis A.N., Sotiropoulos T., Tanou G., Kofidis G., Diamantidis G., Therios E. 2006. Antioxidant and anatomical responses in shoot culture of the apple rootstock $\mathrm{mm}$ treated with $\mathrm{NaCl}, \mathrm{KCl}$, mannitol or sorbitol. Biol. Plant. 50(3), 331-338.

Murashige T., Skoog F. 1962. A revised medium for rapid growth and bioassays with tobacco tissue cultures. Physiol. Plant. 15(3), 473-497.

Nadeau J.A., Sack F. 2002. Control of stomatal distribution on the Arabidopsis leaf surface. Science 296(5573), 1697-1700.

Rai M.K., Kalia R.K., Singh R., Gangola M.P., Dhawan A.K. 2011. Developing stress tolerant plants through in vitro selection-an overview of the recent progress. Environ. Exper. Bot. 71(1), 89-98.

Rzepka-Plevneš D, Kulpa D. 1999. Agronomic properties of rye populations selected for tolerance to nutrition deficiency under laboratory conditions. Biul. IHAR 211, 259-266.

Rzepka-Plevneš D., Kulpa D., Charkot S. 2006. Salt tolerance screening of Pinus sylvestris L. From the dunes of the south-west coast of the baltic sea under in vitro condition. J. Food Agric. Envir. 4(2), 329-334.

Rzepka-Plevneš D., Krupa-Małkiewicz M., Twardowska M., Kurek J., Wyborska K. 2008. Variability of rye varieties and breeding strains tested for tolerance to drought in in vitro cultures. J. Food Agr. Envir. 6(2), 265-271.

Schmidt M.A., Tucker D.M., Cahoon E.B. Parrott W.A. 2005. Towards normalization of soybean somatic embryo maturation. Plant Cell Rep. 24(7), 383-391.

Snyman S.J., Mhlanga P., Watt M.P. 2016. Rapid Screening of Sugarcane Plantlets for In Vitro Mannitol-Induced Stress. Sugar Tech. 18(4), 437-440.

Tanzarella O.A., Pace C.D., Filippetti A. 1984. Stomatal frequency and size in Vicia faba L. Crop Sci. 24, 1070-1076.

Walker D.R., Parrott W.A. 2001. Effect of polyethylene glycol and sugar alcohols on soybean somatic embryo germination and conversion. Plant Cell. Tiss. Organ Cult. 64(1), 55-62.

Wankhade S., Bahaji A., Mateu-Andre's I., Comejo M. 2010. Phenotypic indicators of $\mathrm{NaCl}$ tolerance levels in rice seedlings: variations in development and leaf anatomy. Acta Physiol. Plant. 32, 1161-1169.

Watanabe S., Kojima K., Ide Y., Sasaki S. 2000. Effects of saline and osmotic stress on proline and sugar accumulation in Populus euphratica in vitro. Plant Cell. Tiss. Organ Cult. 63(3), 199-206.

Yang C., Zhao T., Yu D., Gai J. 2009. Somatic embryogenesis and plant regeneration in Chinese soybean (Glycine max (L.) Merr.) - impacts of mannitol, abscisic acid, and explant age. In Vitro Cell. Dev. Biol. - Plant. 45(2), 180-188.

\footnotetext{
Abstract. The aim of this study was to examine an effect of osmotic stress, induced by mannitol (Mn) and sorbitol (So) in concentrations $(0-200 \mathrm{mM}$ ) on seed germination and development of common soybean (Glycine max L.) seedlings in in vitro conditions. The analysis of the effectiveness of the porcession was made by assessing the length of the stems and roots as well as the fresh and dry mass of 3-week-old seedlings. The biometric index values differed depending on the type of substance used. While $\mathrm{Mn}$ at the lowest concentration $(50 \mathrm{mM})$ did not affect the biometric parameters studied, So $(50 \mathrm{mM})$ stimulated the growth of seedlings, root elongation and the number of leaves and fresh weight of plants. The unfavorable effect on biomass was noticed at higher concentrations of both substances. Mn ( $>50 \mathrm{mM}-<150 \mathrm{mM}$ ) negatively influenced the fresh and dry content of the seedlings. In turn, Mn (150 and $200 \mathrm{mM}$ ) also caused growth inhibition, decreased number and length of leaves. So (200 mM) significantly inhibited the growth of seedlings, reducing the dry matter.
} 